\title{
Online Peeragogy: Effects of Videos Developed by Students on Peer Learning and their Impact on Academic Results
}

\author{
Siham Ouhrir ${ }^{1}$, Said Lotfi ${ }^{2}$, Mohammed Talbi ${ }^{3}$ \\ ${ }^{1}$ Observatory of Research in Didactics and University Pedagogy (ORDIPU), Laboratory of Analytical Chemistry \\ and Physico Materials Chemistry (LCAPCM), Faculty of Science of Ben M'sik, Hassan II University of \\ Casablanca, BP 50069, Ghandi, Casablanca Morocco, siham.ouhrir@gmail.com \\ ${ }^{2}$ Evaluation of Sport Sciences and Didactic of Physical Activity, Higher Normal School of Casablanca, Hassan II \\ University of Casablanca, BP 50069, Ghandi, Casablanca Morocco, lotfisaid@gmail.com. \\ ${ }^{3}$ Observatory of Research in Didactics and University Pedagogy (ORDIPU), Laboratory of Analytical Chemistry \\ and Physico Materials chemistry (LCAPCM), Faculty of Science of Ben M'sik, Hassan II University of \\ Casablanca, BP 50069, Ghandi, Casablanca Morocco. talbi.ordipu@gmail.com.
}

\begin{abstract}
This article reports experimental research. Its purpose is to know the impact of educational videos made by students on peer learning. 61 videos were presented, at the end of a physiology and anatomy course, as a deliverable of groups projects. During the next year, the best videos (12) were shared online before class time, to support a flipped classroom and to help students to prepare the examination. The variables selected to assess the impact of this practice on students' learning and academic results, are the score obtained in the quiz of the video, the grades obtained in the participation at the discussions in the classroom and the results of the last examination. The experimental group (126) was compared to a control group (50). The teachers' views about the quality of the discussion in-class time, are taken to enrich the results. The study shows that the videos made by students enhance the comprehension of the course and make peers more engaged in the discussion in the classroom, and more confident in the course content, but there is no difference between the two groups in the academic results.
\end{abstract}

Key words: Academic results, flipped classroom, Peer videos, Peeragogy.

\section{INTRODUCTION}

Since the use of ICTs in the educational field, many changes have been made. Huberman [1], Béchard, J.P. and Peltier [2] specified: technical, conceptual and relationship modifications. The use of educational technologies, according to Lebrun M. [3] generated eight transitions or « movements » in the pedagogical act. Among these mutations are noted: the shift from a work designed for the brightest student to a work for everyone, the transformation of the drowsy class to an active one and the use of other ways for expression. The use of ICT enhance learning and make students develop their skills, Mercy Gana et al.[4]

Several active practices involving students have emerged including: flipped classroom, peer tutoring, peer assessing, collaboration and so on. However, all the collective possibilities are not used and the world of «co» Novel [5] have to be explored. Cristol D. [6]. According to the author, the concept of peer learning is very promising.

Peeragogy, as presented by Rheingold [7] is a kind of educational skill used in peer training. It uses - in French« coformation » translated in English by «co-training» as cited by Cristol op cit.

In addition to redefined roles of teachers and students in high schools, ICT have introduced new educational tools and components. Videos are an example of this innovation. They are exponentially used in Massive Open Online Courses (MOOCs) and in blended learning.

The innovative idea that leads this study is to explore the videos made by students as educational resources, and to find out their added value in enhancing peer learning. This subject is in line of the Hassan II University's policy in using ICT for education. Because, in this institution, several actions were carried on. The last ones have been presented in the second edition of the digital day of Hassan II university of Casablanca $\mathrm{UH} 2 \mathrm{C}$. [8].

In an anatomy and physiology course, we noted that students of the first level have difficulties to understand the most of the speech of teachers. They also can't take notes. The level of French of the students was such that it did not allow a large majority to assimilate the content of the course. This finding is supported by the work of Abdel-Ouahed A. [9] and Haidar M. [10]. The last author mentions the problem of the transition 
from Arabic courses in the secondary school to French in the higher education. Bourderau [11]

This research aims to know the impact of videos developed by students on their peer learning. It attempts to answer the following questions.

- Do students' videos have any impact on the peer understanding of the courses?

- Do watching videos of peers to prepare for a flipped classroom and exams make difference in the results of assessment?

- What is the added value of peer's videos as an additional component used in a flipped classroom?

To answer those questions we make the following assumptions.

- Students who have benefited from the use of peer-made videos as a course medium have properly assimilated the content of the courses.

- The flipped classroom, which uses peer videos, allows students to get better participation scores.

- Students who used the videos to prepare for their exams had better grades than those who did not.

It should be noted that these assumptions are based on the conclusions of the work of Van der Meij and Van der Meij, [12] ; Lloyd and Robertson, [13] ; Traphagan, Kusera and Kishi [14] ; Griffin, Mitchell \& Thompson, [15].

\section{LITTERATURE VIEW}

The theoretical framework of this research is related to socio constructivist theories, including Vigotsky's contribution to the understanding of human learning. According to this author, social interactions and sharing of ideas and experiences are the basic of person's cognitive development and student's interactions reduces the task's difficulty. The "proximal zone of development" is related to the difficulty that the learner can overcome with the help of a peer. Lebrun M. [3] Peer education or peer to peer learning is one of advocated teaching methods for the socio-constructivists. Many practices were experienced to know the impact of students' interactions on their achievement. Many studies targeted the use of ICT in peer learning Ningsih et al. [16].

"Peeragogy", as it is defined by Rheingold [8], is "an educational know-how applied to peer learning", a process that moves away from "I teach, so you learn" syndrome. Cristol D. [7]. It allows people to have an informal education. Corneli et al. [17].

Learning in peeragogy is as old as human being, but now days, the increase of knowledge and the expansion of ICT use, allowed this practice to be revisited in the fashion of 4.0.

The new contribution of Rheingold's work (peeragogy handbook, peeragogy University) is to make people build communities of learners from different countries, ages and profiles. Learners take part in the design of courses.
Peer tutoring is defined by Topping and Ehly [18], as a set of strategies that involve active and interactive mediation of learning from other learners who are not yet professional teachers. It is a similar practice to peeragogy.

According to Gelinas et al.[19], this practice offers many benefits to students. It makes them self-confident in learning. Weidner and Popp, 2007. It can also enhance learning and academic results. Bordes and Arredondo; Fernandes and

Flores; Dancer et al.

If the use of peer learning in a face to face or through synchronous or asynchronous discussions is a common practice, its use online by mediating video capsules or using "webcasting" Kay[20] remain an unusual and poorly referenced practice.

The research of Nesrin Özdenera *and Yasemin Güngörb [21] is one of the rare studies in the field. The authors find that the student's shared videos did not have a positive impact on peers' learning. Another research made by Frydenberg [22] attests that students don't have the same interest in peers' videos. The work shows that videos made by peers have an added value in peers training and learning but they can't take the place of classroom learning.

Kemp et al. [23] used this kind of educational videos to improve students' motivation and to develop their technical skills.

Peltier [24] in a literature review, gave an overview of researches on the use of videos in education, over the decade following 2006. The most of the cited works have studied videos made by teachers and their impact on student's motivation. The impact of those components on student's achievement is not very satisfying. Dobozy and Gross.

Many other researches worked on the video's effects on student's involvement in online learning, given technical characteristics Guo P. J., Kim J., Rubin R. [25], or content Safarali et al. [26], or design. Mayer, cited by Dennen and Myers, [27].

The other key concept in this study is «the flipped classroom ». The concept appear in Erik Mazur's writings, in 1990. It is called «inverted classroom», after this date, by Lage et al.[28].The concept is also cited in the works of Baker [29], and Bergmann \& Sams [30]. It is a pedagogical process of changing the space/time dimensions of the classroom. It can be in type one, two or three given its characteristics. Lebrun [31], Lebrun et al. [32]. Classes are pre-prepared at home using ICT, class time is reserved to more engaging activities than the master class. For Sagaoui [33], it is a question of doing analysis, evaluation and classroom creation (higher level of Bloom's taxonomy).

Several researches have tested the effectiveness of this called «active pedagogy», but many remain cautious about their conclusions: "there is very little scientifically based, empirical research to substantiate the effectiveness of this instructional model" Fraga and Harmon, [34].

For Guilbault and Viau-Guay [35] and Zainuddin and Hajar Halili, [36], understanding tasks and learning in certain types have improved among students. However they did not note any impact on the results of the final examination. 
In Morocco, a study conducted by Ait Moussa [37], showed that students having difficulties in the computer science course were able to improve in the implementation of the work on the platform, and that the "most gifted" students, developed analytical and synthesis skills in classroom activities.

Other studies had previously shown the benefits of the flipped classroom in higher education, we cite: Talley and Scherer [38] and Kong [39], Zhang [40].

In physiology class, the flipped classroom would help to understand the concepts. Tune, et al. [41]. It would also be the source of quality learning for Baepler et al. [42].

From the above, we can say that the results are quite disparate and that these are related to the type of reverse class used, the content and the learned discipline and especially the method of evaluation applied by the researchers. Lebrun and lecoq [43] ask to adapt the evaluation to this type of teaching process, so that they can identify the benefits in terms of skills.

According to Lebrun [44], the most of the researches that tried to compare the methods of teaching « with ICT » and « without ICT», were ended by « no significant difference »

In order to assess the real impact of ICT use on learning, Lebrun advocates a methodology that takes information from all stakeholders: institutional managers, ICT managers, students, teachers, "at different levels of involvement (motivations, tools, uses, cognitive instruments) and at different structural levels (institution, management of training programs, learning achieved)" [45].

This research try to assess the impact of a pedagogical approach: Flipped classroom using student's videos. The information is taken from teachers and users, in this case: students.

\section{METHODOLOGY}

\subsection{Protocol of study}

This work is experimental study that is part of an action research that took place over two academic years 2016/2017 and 2017/2018.

The first step in this study was the production of video capsules by students $\left(n^{\circ} .125\right)$ of the first year of a professional degree in teaching. These videos are resources for physiology and anatomy courses. They were the result of working in groups ranging from 2 to 6 members. They covered part of the course (optional). The capsules were delivered by students at the end of the semester after learning all course contents.

The second step is the study we outline in this article: The previously developed videos, 61 capsules, were evaluated by teachers in both subjects, to decide their quality and the veracity of their content. Only 12 video capsules were selected and made available to students of first-year class: 2017/2018. These videos, which lasted up to 8 minutes, were uploaded so that students could view and download them at will. The videos were shared before class as a resource for a flipped classroom. The capsules available on digital workspaces were to be used by students to better interact in-class time.
The face to face course combined interaction about the videos with an additional and complementary contribution. The course is given to about 60 students for one hour and a half a week. Other resources were available to students.

At the end of the semester, students were questioned about the added value of the videos.

The two teachers were also asked about the effect of this experience on the face to face course.

\subsection{Data collection}

After viewing the video, students were asked to answer a quiz about the content of the video sequences. These tests contained 4 questions and each student scored from 0 to 4 points. The selected variables are:

- Understanding the speech and content of videos: assessed as a result of the quiz results.

- The questions in the quiz contained requests to explain concepts or mechanisms presented in the video. Example: On a video that shows how the heart works we asked the question: what is a heart revolution?

- Class participation: A score is assigned to each student's participation in the class debates.

- An informal interview was conducted with the two teachers conducting the course. The question was: the impact of the pedagogical process used on the course.

- The final exam score: For the final exam, we made sure to have the same registers of questions as those given two years earlier. The content evaluated is the same.

These results are reported to those of a control group taken from a former promotion.

- The number of people who have used the videos is directly recorded through the platform that identifies students who have logged in. It is an indicator to support the exploitation of results.

- The added value of this flipped classroom experience based on peer videos.

- A questionnaire was completed by students to report on their experience of using peers' videos as course support.

- This measuring instrument contains fourteen questions, including an open question focused on the added value of the use of these videos in the course. In this study, we will only exploit this question:

What added value do you place on the use of peer video in your course?

The results of this question will have a definite impact in the findings of this study. Because, as Lebrun points out [43], the numerical results of the processes: "with the ICT device" and "without the ICT device", are insufficient to judge the value of the dispositive.

\subsection{Sample}

The sample used in this study is a random sample that took what was available. We took the whole 2017/2018 promotion. Table 1. 
The control group in this study is a group taken from a previous promotion: that of $2014 / 2015$. This group had the same teachers, the same courses and above all was evaluated on the same content and in the same way. The only difference is that the GT students had no support before the course.

This choice was made because, first, the variable taken into account was the grades obtained, in-class participation and in the final exam, which is easy to compare. Second, and this is the real constraint because the videos can be shared between the sample and the control group, if the sample had been caught in the same promotion, which would distort the results.

Table 1: Sample of the study

\begin{tabular}{|l|c|c|c|}
\hline Sample & Male & Female & Total \\
\hline $\begin{array}{l}\text { Experimental } \\
\text { group }\end{array}$ & 69 & 57 & 126 \\
\hline $\begin{array}{l}\text { Control } \\
\text { group }\end{array}$ & 36 & 14 & 50 \\
\hline
\end{tabular}

\subsection{Data analysis}

Data are analyzed by ANOVA II, comparing scores mean of variables between the experimental and control groups. We examined effect of group, gender, and their interaction $(\mathrm{p}<0.05)$.

\section{RESULTS}

Before judging the quality of learning, it was imperative to ensure that students used the digital resources available to them.

The platform recorded the following data: Table 2

Table 2: Percentage of the use of the videos

\begin{tabular}{|c|c|}
\hline Mention & \% of use of the video \\
\hline Yes & $9,09 \%$ \\
\hline No & $90,90 \%$ \\
\hline Total & $100 \%$ \\
\hline
\end{tabular}

The rate of video usage allows us to justify our conclusions in the next steps.

The variables treated in this study are:

\subsection{Understanding the content of videos:}

The results obtained in the quiz are as follows in Table 3.

Table 3: Percentage of students per mark obtained in the Quiz

\begin{tabular}{|c|c|}
\hline Mark & \% of students \\
\hline 0 & $0,00 \%$ \\
\hline 1 & $13,43 \%$ \\
\hline 2 & $24,37 \%$ \\
\hline 3 & $31,34 \%$ \\
\hline 4 & $30,84 \%$ \\
\hline Total & $100 \%$ \\
\hline
\end{tabular}

We find that for this variable, the highest percentages of students are between 3 points and 4 points. Students with between 3 and 4 correct answers on the four questions asked were $62.189 \%$.

\subsection{The classroom participation}

Following the assessment of the courses supported by peers' videos, the recorded results are as follows: Table 4.

Table 4: Statistical characteristics of scores obtained in classroom discussion participation by experimental and control groups by gender

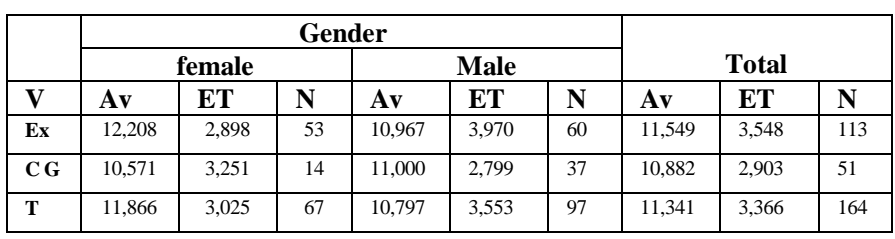

V: Values, Ex: Experimental Group, C G: Control Group, T: Total, Av: Average, ET: Ecart Type, N: Number.

Table 5: Compared average scores between the experimental and gender control groups by ANOVA II

\begin{tabular}{|c|c|c|c|c|c|c|}
\hline \multicolumn{7}{|c|}{ Independent variable: Score } \\
\hline $\begin{array}{c}\text { Effect } \\
\text { Source on } \\
\text { scores } \\
\text { Variation }\end{array}$ & $\begin{array}{l}\text { Sum of } \\
\text { square } \\
\text { type III }\end{array}$ & ddl & $\begin{array}{l}\text { Middle } \\
\text { square }\end{array}$ & $\mathbf{F}$ & $\begin{array}{c}\text { Signifi- } \\
\text { cation } \\
P\end{array}$ & $\begin{array}{c}\text { Partial } \\
\text { Etat } \\
\text { square }\end{array}$ \\
\hline $\mathbf{C M}$ & $60,799^{\mathrm{a}}$ & 3 & 20,266 & 1,815 &, 146 & 033 \\
\hline Constant & 14942,680 & 1 & 14942,680 & 1338,591 & 000 & ,893 \\
\hline $\begin{array}{ll}\text { Effect } & \text { of } \\
\text { type } & \text { of } \\
\text { group } 1 & \end{array}$ & 19,172 & 1 & 19,172 & 1,718 & $\begin{array}{l}, 192 \\
((\mathrm{NS})\end{array}$ & 011 \\
\hline $\begin{array}{l}\text { Effect of } \\
\text { gender } 2\end{array}$ & 4,925 & 1 & 4,925 & ,441 & $\begin{array}{r}, 508 \\
((\mathrm{NS}) \\
\end{array}$ &, 003 \\
\hline $\begin{array}{l}\text { Effect of } \\
\text { interaction } \\
1 / 2\end{array}$ & 20,801 & 1 & 20,801 & 1,863 & $\begin{array}{c}, 174 \\
((\mathrm{NS})\end{array}$ & ,012 \\
\hline Error & 1786,079 & 160 & 14,287 & & & \\
\hline Total & 22942,000 & 164 & & & & \\
\hline $\begin{array}{l}\text { Corrected } \\
\text { total }\end{array}$ & 1846,878 & 163 & & & & \\
\hline a. $\mathrm{R}-2=$, & (R-2 adju & $\mathrm{u}-$ & & & & \\
\hline
\end{tabular}

\section{M: Corrected model}

NS: no significant effect

Through ANOVA II analysis, no significant effects are found either between the averages of the experimental and control group scores $(11,549$ - 3.548; 10,882 -2,903), nor between gender. We also observed no interaction between these two factors. 


\subsection{The opinion of the teachers responsible for the course on students' participation in the discussion}

The analysis of interviews with the teachers revealed the following results: Both teachers were unanimous in saying that the use of peer videos as a tool of flipped classroom has many impacts: Table 6

Table 6: Teacher's view about classroom participation of control and experimental group

The level of discussion and analysis among G EX. students is higher

The number of students involved in the discussions was higher compared to the GT.

Students have more information to answer questions asked during the course. Students have better self-confidence and dare to communicate in groups.

The quality of the answers is better in the G ex.

\subsection{The results of the final exam.}

Following the assessment of the courses supported by peers' videos, the recorded results are as follows: Table 7

Table 7: Statistical characteristics of scores obtained in classroom discussion participation by experi-mental and control groups by gender

\begin{tabular}{|c|c|c|c|c|c|c|c|c|c|}
\hline & \multicolumn{6}{|c|}{ Gender } & & & \\
\hline & \multicolumn{3}{|c|}{ female } & \multicolumn{3}{|c|}{ Male } & \multicolumn{3}{|c|}{ Total } \\
\hline V & Av & ET & $\mathbf{N}$ & Av & ET & $\mathbf{N}$ & Av & ET & $\mathbf{N}$ \\
\hline Ex & & & & & & & & & \\
\hline & 11,87 & 3,48 & 53 & 9,98 & 4,53 & 60 & 10,86 & 4,16 & 113 \\
\hline CG & 10,54 & 3,34 & 14 & 10,64 & 2,89 & 37 & 10,60 & 2,99 & 51 \\
\hline$T$ & 1159 & 3,47 & 67 & 10,23 & 3,98 & 97 & 10,78 & 3,83 & 164 \\
\hline
\end{tabular}

V: Values, Ex: Experimental Group, C G: Control Group, T: Total, Av: Average, ET: Ecart Type, N: Number.

Table 8: ANOVA 2 comparison of average obtained by experimental and control group by gender.

\begin{tabular}{|c|c|c|c|c|c|c|}
\hline \multicolumn{7}{|c|}{ Independent variable: Score } \\
\hline $\begin{array}{c}\text { Effect } \\
\text { Source on } \\
\text { scores } \\
\text { Variation }\end{array}$ & $\begin{array}{l}\text { Sum of } \\
\text { square } \\
\text { type III }\end{array}$ & ddl & $\begin{array}{l}\text { Middle } \\
\text { square }\end{array}$ & F & $\begin{array}{l}\text { Significa- } \\
\text { tion } P\end{array}$ & $\begin{array}{c}\text { Partial } \\
\text { Etat } \\
\text { square }\end{array}$ \\
\hline $\mathbf{C M}$ & $103,221^{(\mathrm{a})}$ & 3 & 34,407 & 2,408 & ,069 &, 043 \\
\hline Constant & 13808,360 & 1 & 13808,360 & 966,530 & ,000 & ,858 \\
\hline 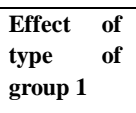 & 3,371 & 1 & 3,371 &, 236 & ,628 (NS) & ,001 \\
\hline $\begin{array}{l}\text { Effect of } \\
\text { gender } 2\end{array}$ & 24,007 & 1 & 24,007 & 1,680 & ,197 (NS) & 010 \\
\hline $\begin{array}{l}\text { Effect of } \\
\text { interaction } \\
1 / 2\end{array}$ & 29,625 & 1 & 29,625 & 2,074 & ,152(NS) & ,013 \\
\hline Error & 2285,844 & 160 & 14,287 & & & \\
\hline Total & 21459,750 & 164 & & & & \\
\hline $\begin{array}{l}\text { Corrected } \\
\text { total }\end{array}$ & 2389,066 & 163 & & & & \\
\hline
\end{tabular}

\section{M: Corrected model \\ NS: no significant effect}

Through the analysis by ANOVA II, no significant effects were found either between the averages of the experimental and control group scores (10.86-4.16 vs. 10.60-2.99), nor between gender, and we also observed no interaction between these two factors.

\subsection{The results of the question about the added value of peer videos.}

The results of the peer video added value question are as follows: Table 9.

Table 9: The results of the added value of the use of peers' videos in the course

\begin{tabular}{|l|l|l|l|l|l|}
\hline Gender & Content & Efficiency & Easy use & $\begin{array}{l}\text { Virtues } \\
\text { of videos }\end{array}$ & Total \\
\hline Female & $1,52 \%$ & $27,27 \%$ & $3,03 \%$ & $7,58 \%$ & $39,39 \%$ \\
\hline Male & $3,03 \%$ & $40,91 \%$ & $1,52 \%$ & $15,15 \%$ & $60,61 \%$ \\
\hline Total & $4,55 \%$ & $68,18 \%$ & $4,55 \%$ & $22,73 \%$ & $100 \%$ \\
\hline
\end{tabular}

The items: content, efficiency, easy use, virtues of video, were chosen to group similar responses and allow their easy processing.

In "content" we put the answers such as: "animations and diagrams they offer", "videos give details", "The illustrations allow us to better understand", "Simple speech allows us to better understand".

The "efficiency" item contains the typical responses: "They facilitate understanding," "facilitate learning," "enable learning in less time," "facilitate memorization."

Under the group: "easy use" we put the answers of the type: "easy to use," "quick information in less time."

For the whole: "video virtues": it includes typical responses: "videos explain better," "visual audio helps you understand better," "videos help you review content," "videos help you focus," "videos help you relive the course".

From the results, we can only see that a majority of people give peer videos, added value in the understanding of the course and learning. The value associated with the virtues of videos comes in second place.

\section{DISCUSSION}

By referring to the results of student points obtained as a result of quiz responses, we can say that the learning videos gave students understandable content. In fact, $62.19 \%$, had more than three correct answers and 86, 57\% had 2 correct answers, out of the four questions asked. This shows that the degree of assimilation of content is quite important.

Videos that were used only as "additional resources" Boullier (2015) [45] in the presentation course, were administered well before the lecture, which would imply the novelty of the content of these capsules for students. 
We notice that students understood and retained the information after viewing the videos. This may be due to the simple language of their peers, since the difficulty of taking notes in teachers' courses is partly related to the speech given by the university teacher (choice of words and flow of language) [10].

The amount of information presented in the video capsules may also be an explanation for this retention of information among students. Indeed, the fact that the target duration of video: between 3 and 5 minutes with a tolerated margin of 3 minutes, was imposed meant that the parts of the course treated were short. This data has led to the need for attention in short periods of time. This idea is supported by student responses that give peer videos the added value of attracting attention and engaging (Video Views). This result may also be due to the casual and informal aspect of the video made by the students, Guo P. J., Kim J., Rubin R. (2014) [25], which makes it more engaging for their peers.

$68.18 \%$ of respondents stated that peer videos are effective in understanding courses and learning" "they help to understand concepts" and "they allow the repetition of the course." These results can also be supported by the fact that student-made capsules are efficient because they present "speeches with simple and easy-to-understand words" as some students point out.

From the above, we can conclude that the videos of peers used as a medium of flipped classroom have allowed students to better understand the course and to master the concepts presented, thanks to the simplicity of students' discourse, their casual and engaging appearance and the amount of information contained in these tools.

\section{For the results of class participation}

Results from statistical analysis of class participation scores between the experimental and control groups show that there is no significant difference between the scores obtained. However, the teachers in charge of the module found that the group that used peer videos prior to the course had "information to share," were more engaged in discussions and pushed the analysis to a higher level compared to their predecessors.

The professors also noted that students were fluent in presenting answers to questions asked in class and appeared more confident in their interventions.

The effects of the use of e-learning reported by Kwan (2009) that include: improved interest in the subject taught and increased self-confidence in the field of knowledge, agree with the results previously cited.

\section{For the results of the final exam}

The difference between the end-of-semester results of the control group and the experimental group is not significant. This goes towards the conclusions noted by the research conducted by par Özdenera N., Güngörb Y., Zdenera N. [21], Dobozy and Cross (2010).
The results obtained do not mean that these videos do not have a real impact on the gains but it is essential to apprehend them in a system. Lebrun M. [6], Kay [20].

If we consider the added value of the videos and the views of the teachers, we can notice other acquisitions, for example, the information skills that allowed to use the tool, the communication skills, the analytical spirit developed during classroom discussions, and the strengthening of the sense of self-confidence in the Experimental group.

In addition to these developed skills, students approve the effectiveness of peer videos as a learning tool. They also like to save time and effort in reviewing courses. They find that these videos, through their simplicity and content, improve learning and understanding of the courses.

\section{CONCLUSION}

In this work, we saw that videos developed by students are very helpful for their peers in preparing the courses and exams. The added value of those tools is that they explain contents in simple words. They, also, offer everyone the possibility to learn according to his needs and availability.

Using students' videos as supplementary resources can help teachers to develop online courses with less cost and time. This can be very efficient in many countries where online courses are not subsidized by governments. The principal requirement is to select the best ones (quality of image and sound, veracity of content, pedagogical resources used...). This research was conducted in a class of 125 people. 61 capsules were presented. The two teachers responsible for the selection, retained only 20 videos in accordance with the criteria. Doing the same thing in the university, with a very large number of students will be not very easy. The work must be done by a team of technicians and teachers.

The second important thing to note in this work is that students' videos can present many subjects to enhance learning. Students can explain an idea, give a solution or demonstrate how to do things and so on. The content of videos may differ depending on students' needs.

The third idea to retain is that the students who worked in the conception of the videos developed technical, informational and communication skills and a very important pedagogical know-how. This is a very important thing for their future job of teachers. , Mercy Gana et al. [46]

The true value of flipped classroom using students' videos is a trail to explore. In this research, we used the results of students as criteria added to teachers' views about the work in the classroom "with" and "without" the pedagogical dispositive. In fact, other evaluation tools, as mentioned by Lebrun [44], have to be used in such studies.

\section{REFERENCES}

1. M.A. Huberman. Comment s'opèrent les changements en éducation: contribution à l'étude de l'innovation. Paris, UNESCO/BIE, 1973. 
2. J.-P. Béchardet, P. Pelletier. Développement des innovations pédagogiques en milieu universitaire: un cas d'apprentissage organisationnel. In D. Raymond, Nouveaux espaces de développement professionnel et organisationnel (p.131-149). Sherbrooke: Éditions du CRP, 2001.

3. M. Lebrun, Théories et méthodes pédagogiques pour enseigner et apprendre, Quelle place pour les TIC dans l'éducation? De boeck Bruxcelles. 2010.

4. S.Mercy Gnana Gandhi, J.Amutha Monika,The Role of Emerging Technologies in Standardizing Language Teaching and Learning through 5C's, International Journal of Emerging Technologies in Engineering Research (IJETER), Volume 6, Issue 4, April (2018)

5. S. Novel, La vie share : mode d'emploi. Consommation, partage et mode de vie collaboratif. Paris : Manifesto. 2013.

6. D. Cristol, Les communautés d'apprentissage : apprendre ensemble, Savoirs, [online] vol. 2017, vol. 43, no. 1 , pp. 10-55.

https://doi.org/10.3917/savo.043.0009

7. H. Rheingold, The peeragogy Handbook (2015).

8. UnivInfo, $2018, \mathrm{~N}^{\circ} 9$ Mai-Juin. www.univh2c.ma/_files/fle_180807145114.pdf [Accessed27/10/19].

9. A. Abdelouahed, Reflection about integrating ICT in teaching and learning of French: the case of Moroccan universities, Francine .net, 2014, n ${ }^{\circ}$ 8, Avril.

10. M. Haider, Pour une didactique contextualisée du français scientifique à l'université. L'exemple de la biologie et de la géologie à l'université de Kénitra (Maroc). Revue de sociolinguistique et de sociologie de la langue française, 2015, vol. $41 \mathrm{n}^{\circ} 2$.

11. F., Bourdereau, Politique linguistique, politique scolaire, 2006, Paris, A Colin, p. 25 - 34. https://doi.org/10.3917/lfa.154.0025

12. H. Van der Meij, Van der Meij J., A comparison of paper-based and video tutorials for software learning, Computers \& education, 2014, 78, 150-159. https://doi.org/10.1016/j.compedu.2014.06.003

13. S. A. Lloyd, Robertson C. L., Screencast tutorials enhance student learning of statistics, Teaching of Psychology, 2012, Vol.39, $\mathrm{n}^{\circ}$ 1, 67-71. https://doi.org/10.1177/0098628311430640

14. T. Traphagan, J.V. Kusera and K. Kishi. Impact of class lecture webcasting on attendance and learning. Educational Technology Research and Development, 2010, Vol. 58, n ${ }^{\circ}, 19-37$. https://doi.org/10.1007/s11423-009-9128-7

15. D.K. Griffin, D. Mitchell and S.J. Thompson. Podcasting by synchronizing PowerPoint and voice: What are the pedagogical benefits?, Computers \& Education, [online], 2009, Vol.53, $\mathrm{n}^{\circ} 2$, 532-539. https://doi.org/10.1016/j.compedu.2009.03.011

16. S. R. Ningsih, Z. M. Effendy, Syah N., Implementation of cooperative learning model on e-assignment responsiveness at higher education, International
Journal in Emerging Technologies in Learning, Vol. 14, $\mathrm{n}^{\circ} 18,2019$.

https://doi.org/10.3991/ijet.v14i18.10752

17. Corneli et al cité in cristol Denis 2017

18. K. Topping, S. Ehly, Peer assisted learning: a framework for consultation, Journal of Educational and Psychological Consultation, 2001, Vol.12, $\mathrm{n}^{\circ} 2$, 113-132.

19. E. S. Gélinas, R. M. Berger, D. Balbinott, M. C. Lalande, L'apprentissage par la pratique : vécus d'étudiants en psychologie impliqués dans la création de tutoriels informatisés en méthodes quantitatives, Société française de statistiques, 2018, Vol. 9, $\mathrm{n}^{\circ} 1$.

20. R. H. Kay, Exploring the use of video podcasts in education: A comprehensive review of the literature. Computers in Human Behavior, 2012, Vol.28, n³, pp. 820-831.

https://doi.org/10.1016/j.chb.2012.01.011

21. N. Özdenera *, Y. Güngörb, Effects of video podcast technology on peer learning and project quality, Procedia Social and Behavioral Sciences 2, [online], 2010, Vol. 22, $\mathrm{n}^{\circ} 17-222$. https://doi.org/10.1016/j.sbspro.2010.03.311

22. M. Frydenberg, Principles and Pedagogy: The Two Ps of Podcasting in the Information Technology Classroom, information systems education journal, 2008, Vol.6, nº 6 , February 4

23. J. Kemp, A. Mellor, R. Kotter, J. W. Oosthoek, Student-produced podcasts as an assessment tool: An example from geomorphology. Journal of Geography in Higher Education, [online], 2012, Vol. 36, ${ }^{\circ} 1$, 117-130.

https://doi.org/10.1080/03098265.2011.576754

24. C. Peltier, Usage des podcasts en milieu universitaire : une revue de la littérature. International Journal of Technologies in Higher Education, 2016, Vol. 13, $\mathrm{n}^{\circ}$ 2-3, pp. 17-35.

25. P. J. Guo, J. Kim, R. Rubin, How video production affects student engagement: An empirical study of MOOC videos, Reseachgate, Mars 2014.

26. S. K. Safarali, H. Hamidi, The Impact of Videos Presenting Speakers' Gestures and Facial Clues on Iranian EFL Learners' Listening Comprehension, International Journal of applied linguistics and english literature, 2012, $\mathrm{Vol} 1, \mathrm{n}^{\circ} 6$. https://doi.org/10.7575/ijalel.v.1n.6p.106

27. V. Dennen, J. Myers, Podcast Pedagogy: Message Design, Motivation, and Learning. In J. Sanchez \& K. Zhang (Eds.), "Proceedings of E-Learn", World Conference on E-Learning in Corporate, Government, Healthcare, and Higher Education, 2010, pp. 43-49. Orlando, Florida, USA: Association for the Advancement of Computing in Education (AACE). Retrieved January 27, 2019.

28. M. J. Lage, G. J. Platt, , M. Treglia. Inverting the Classroom: A Gateway to Creating an Inclusive 
Learning Environment. 2000. The Journal of Economic Education, Vol. 3, n¹, 3043.

29. J. W. Baker, The Classroom Flip: Using Web Course Management Tools to Become the Guide by the Side (917). Selected paper, $11 \mathrm{~h}$ International Conference on College Teaching and Learning.

30. J. Bergmann, A. Sams. Flip your classroom: reach every student in every class every day. Eugene, Oregon: International Society for Technology in Education. 2012.

31. M. Lebrun, La classe inversée au confluent de différentes tendances dans un contexte mouvant. Dans A. Dumont et D. Berthiaume (dir.), La pédagogie inversée, p. 13-38. 2016, Louvain-la Neuve, Belgique De Boeck Supérieur.

32. M. Lebrun, C. Gilson, C. Goffinet, Vers une typologie des classes inversées, Education et Formation, 2017, e-306.

33. N. Saragawi, Flipping an introductory programming course: yes, you can!, Journal of Computing Sciences in Colleges, 2013, Vol. 28, $\mathrm{n}^{\circ} 6,186188$.

34. L. M Fraga, J. Harmon. The flipped classroom model of learning in higher education: An investigation of preservice teachers' perspectives and achievement. Journal of Digital Learning in Teacher Education, 2015, Vol. 31, $\mathrm{n}^{\circ} 1, \quad$ 18-27. doi:10.1080/21532974.2014.967420.

35. M. Guilbault, A. Viau-Guay. La classe inversée comme approche pédagogique en enseignement supérieur : état des connaissances scientifiques et recommandations. Revue internationale de pédagogie de l'enseignement supérieur, [online], 2017, Vol. 33, $\mathrm{n}^{\circ} 1$.

36. H. Zhang, A flipped classroom-based education system for higher education. International Journal in Emerging Technologies in Learning, Vol. 14, n¹6, 2019. https://doi.org/10.3991/ijet.v14i16.11152

37. Z. Zainuddin, S.H. Halili, Flipped Classroom Research and Trends from Different Fields of Study. International Review of Research in Open and Distributed Learning, 2016, Vol.17 n ${ }^{\circ}$ 3, p. 313-340. https://doi.org/10.19173/irrodl.v17i3.2274

38. A. Ait Moussa . An experience in Moroccan University using flipped classroom. International conference on ICT for education and training and International conference on computing in Arabic. 1-3 Aug, 2017.

39. C. Talley, S. Scherer, The Enhanced Flipped Classroom: Increasing Academic Performance with Student-recorded Lectures and Practice Testing in a "Flipped » STEM Course. The Journal of Negro Education, [online], 2013, Vol. 82, n³, 339347. https://doi.org/10.7709/jnegroeducation.82.3.0339

40. S. C. Kong. Developing information literacy and critical thinking skills through domain knowledge learning in digital classrooms: An experience of practicing flipped classroom strategy. Computers and Education 2014 , Vol78,160173. https://doi.org/10.1016/j.compedu.2014.05.009

41. J. D. Tune, M., Sturek, D. P. Basile, Flipped classroom model improves graduate student performance in cardiovascular, respiratory, and renal physiology. AJP Advances in Physiology Education, [online], 2013, Vol. 37, nº 316320.

42. P. Baepler, J. D. Walker, M. Driessen, It's not about seat time: Blending, flipping, and efficiency in active learning classrooms. Computers et Education, 2014, Vol.78,227236.

https://doi.org/10.1016/j.compedu.2014.06.006

43. M. Lebrun, J. Lecoq. Classes inversées : enseigner et apprendre à l'endroit !, Futuroscope : Canopé edition. 2015. https://www.learntechlib.org/primary/p/35508/.

44. M. Lebrun. Impacts des TIC sur la qualité des apprentissages des étudiants et le développement professionnel des enseignants : vers une approche systémique. Sciences et Technologies de l'Information et de la Communication pour l'Éducation et la Formation, ATIEF, 2011, 18, 20 p. hal-00696443

45. D. Boullier. Quel rôle pour les profs ? Revue Projet, 2015, Vol.4, n³47, 80-87. Journal of Educational Computing Research, 14(3), 243-268.

46. S. Mercy. Gnana Ghandi, J. Amutha Monica, Clarification to the Teachers of Technical Institutions for Managing Next Generation Classrooms, International Journal of Emerging Technologies in Engineering Research (IJETER) Volume 6, Issue 3, March (2018). 